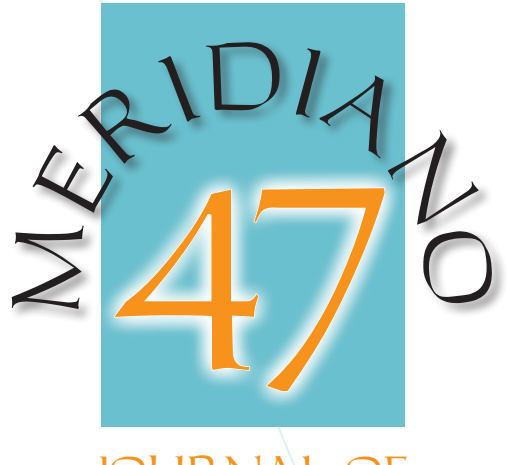

JOURNAL OF

GLOBAL STUIDIES

ISSN 1518-1219

http://www.meridiano47.info

\title{
Maurício Vieira
}

Universidade Estadual do Ceará, Laboratório de Estudos da Conflitualidade e da Violência, Fortaleza - CE, Brazil (mauriciovieira.ce@gmail.com)

\section{Acknowledgments}

I would like to thank the Foundation for Science and Technology (FCT) for providing financial support to the Ph.D. Program in International Politics and Conflict Resolution (PD/BD 113981/2015); to the Researcher Professor Gregory M. Reichberg, who provided valuable comments on this paper during the Ph.D. Course "Business for Peace: A New Dawn for International Peacebuilding?" that took place at the Peace Research Institute Oslo (PRIO) on March 2017; and to the comments during the panel "Citizenship and Peacebuilding: Challenges and Prospects" at the ISA CISS/IDSS Conference 2017 held in Bologna, Italy.

\section{Copyright:}

- This is an open-access article distributed under the terms of a Creative Commons

Attribution License, which permits unrestricted use, distribution, and reproduction in any medium, provided that the original author and source are credited.

- Este é um artigo publicado em acesso aberto e distribuído sob os termos da Licença de Atribuição Creative Commons, que permite uso irrestrito, distribuição e reprodução em qualquer meio, desde que o autor e a fonte originais sejam creditados. 
represents an oppositional way to the state of war, armed conflict, and violence, the positive approach to peace reveals the possibility of achieving this objective through the identification of different levels of analysis in which the broad sense of peace in which is embedded. Such levels, nevertheless, are defined, in the scope of this paper, as a fragmentation process in which peace within an institutional approach is framed continuously and reframed. This process presumes not only a need for interpreting the concept of positive peace after more than five decades from its emergence but clarification on how this approach is put into practice by the United Nations through the Sustainable Development Goals (SDGs). Considering that fragmentation can be understood as a permanent process of cause and consequence and, also, as a dialectic relationship between deconstruction and reconstruction, as well as between connection and disconnection that underlies the analytical potential of the term, how it can perceive into a peace concept?

Embedded in Galtung's main contribution, this paper combines conceptual and theoretical frameworks to the argument that the way the Millennium Development Goals (MDGs) were conceived and how they were reframed as part of the conceptualization of its predecessor Sustainable Development Goals (SDGs) reflects a process of fragmentation among the notion of strategies designed to achieve positive peace. To analyze the fragmentation perspective into a peace conceptualization, this paper is structured in three parts: it first explains the concept of fragmentation within the notion on framing approach; second, it builds upon on the idea of positive peace to enable an understanding of the fragmentation of the goals defined as part of the Sustainable Development approach; and, third, how the fragmentation of peace creates a new pattern of promoting a global and shared agenda, which gained scope through a preliminary comparison based on the establishment of the MDGs and the SDGs by the United Nations (UN).

\section{Fragmenting peace: a conceptualization}

The definition of fragmentation rests on its etymology. Originated from the Latin fragmentum, which means "broken piece"; and frangere, referring "to fall to pieces" or "to break"; fragmentation, following Deffner and Hoerning (2011), refers to a result of the cleavage and the process of breaking into pieces. Even they affirm that the fragment appears as part of an original entity that may no longer perform as such, the fragmented piece plays an essential role in providing a constant re-conceptualization of its unique structure. In their analysis, Deffner and Hoerning (2011) point out that the research on fragmentation should correlate three elements: i) a former entity, ii) a current perception, and iii) an emerging pattern. When the authors take these three elements, they do not want to separate and analyze them individually. However, they consider these elements to understand fragmentation as a process of deconstruction and reconstruction in which evidences a former, deconstructed entity, at the same time it represents a current state or, at least, its perception, while also indicating a process of reconstructing a newly emerging pattern (Deffner and Hoerning, 2011: 2). 
For them, the condition in which the deconstructing process and its consequent pattern may be seen as incomplete one will depend on the type of social practice. At this point, Adler and Pouliot (2011a, 2011b) assume that practices are not merely descriptive 'arrows' that connect the structure to agency and back, "but rather the dynamic material and ideational processes that enable structures to be stable or to evolve, and agents to reproduce or transform structures" (Adler and Pouliot, 2011a: 6, 2011b: 5). Taking this scenario for granted, Deffner and Hoerning (2011) corroborate this thought, also assuming that "where the former entity is perceived as fragmented, deconstructed, non-existing, an emerging pattern is being reconstructed in daily social practice" (Deffner and Hoerning, 2011:3). For this reason, their conceptualization on fragmentation

\begin{abstract}
May either appear as a temporary re-structuring with fragments as remnants of former structures or as an intrinsic process of increasingly polarized modern (and postmodern) societies with fragments as both highly interrelated and disconnected parts of society as a whole. In the first case, fragmentation as a term is related to a lack of understanding of newly emerging structures (Deffner and Hoerning, 2011).
\end{abstract}

This dialectic on the fragmentation process mentioned by the authors, therefore, should not obscure social relations based on hierarchies and inequalities of social heterogeneity, as they point out. The vantage of fragmenting the social reality to reconstruct it and fragment it again contributes to "analytically distinguish disconnections and interwovenness of societal parts that differ in terms of their power to manipulate socio-spatial structures and patterns" (Deffner and Hoerning, 2011: 3). The new pattern that emerges within the fragmentation can be viewed, as Franklin et al. (2002) point out, as both a process (that which causes fragmentation) as an outcome (the state of being fragmented). Their analysis suggests that fragmentation represents a transition from being whole to being broken into two or more distinct pieces and that "the outcome of fragmentation is binary in the sense that the resulting landscape is assumed to be composed of fragments (e.g., forest) with something else (the non-forest matrix) between the fragments" (Franklin et al. 2002: 22). However, the perception of fragmentation mentioned above and the one proposed in this paper differs from the understanding conceived by Cunningham (2016).

The author analyses fragmentation in the context of conflict and peace while assuming a perspective that fragmentation refers to a less level of social cohesion among actors within these contexts. Taking the scenario of internal armed conflicts, for example, Cunningham (2016) points out that they are described as fragmented when multiple rebel groups are fighting the state. The author explains this fragmentation perspective emphasizing that, on the one hand, armed "conflicts can be fragmented if there are multiple 'sides' [and that] each side is then made up of actors that are more or less cohesive" (Cunningham, 2016: 4) and, on the other hand, “actors or 'opposition movements' are said to be fragmented when they consist of multiple internal factions" (Cunningham, 2016: 4). Based on the context of peace, Cunningham (2016) distinguishes two types of fragmentations: 
intentional and unintentional. Based on the first type, a peace process promotes fragmentation when states choose a peace process in which only some actors can participate in detriment of others, creating opposition organizations that have incentives to shed links to one another (Cunningham, 2016: 9). On unintentional fragmentation, Cunningham (2016) explains that in a peace process, the opposition is fragmented, competition among organizations can create incentives for spoiling or joining a peace process. "As actors attempt to discern the likely outcome of a peace process, individual organizations look to their survival and influence in addition to their goals in the conflict" (Cunningham, 2016: 9).

In the scope of this article, the perspective on fragmentation lays on the notion of breaking into pieces to construct a unity, cohesion, and coherence through small parts that represent a whole structure. It is, in essence, an analysis of how the top-down approach conceives its intervention to promote peace by the international system within different strategies. However, I do not discard the possibility of considering Cunningham's (2016) contribution in analyzing fragmentation on the bottom level, in which it can create and perpetuates social cleavages when implemented, evidencing an opposite perception of what fragmentation means and implies (Waage et al. 2010). But, for the analysis proposed in this discussion, peace is being fragmented to establish social order, social cohesion as a universal global value, as well as a standard, common, and disseminated agenda.

At this point, social cohesion represents "the capacity of a society to ensure the welfare of all its members, minimizing disparities and avoiding polarisation" (CDCS, 2004), as well as it is understood as "the belief - held by citizens in a given nation-state - that they share a moral community, which enables them to trust each other" (Larsen, 2013, 2014). In this sense, fragmentation can be understood as a continual process in which both cause and consequence belong to it. Nevertheless, the notion of fragmentation does not lay in a vacuum. It is an inherent aspect of a framing perspective for understanding social reality. As Rein and Schön argue, framing is a way of "selecting, organizing, interpreting, and making sense of a complex reality to provide guideposts for knowing, analyzing, persuading, and acting" (1993: 146). In their perspective, framing is a term that "capture[s] different features of the processes by which people construct interpretations of problematic situations, making them coherent from various perspectives and providing users with evaluative frameworks within which to judge how to act" (1993: 146). For framing, Moncrieffe assumes that it "refers to how we understand something to be a problem, which may reflect how issues are represented (or not represented) in policy debates and discourse" (2007: 2).

Following Berger, frame "refers to this inevitably relational dimension of meaning" (1974: xiii) in which it "is only a particularly tangible metaphor for what other sociologists have tried to invoke by words like 'background,' 'setting,' 'context,' or a phrase like 'in terms of'” (1974: xiii). On the same line of thought, Entman (1993) affirms that frames define problems, diagnose causes, make moral judgments and suggest remedies, which means that there is a logic of identifying costs and benefits of finding and establishing cultural values in order not only to evidence a problem, but most importantly, defining parameters for action (1993: 52). In other words, frames work as guiding 
"the ways situational participants perceive their social realities and (re)present these to themselves and others" (van Hulst and Yanow, 2014: 3); as a reflection of actors' organizing principles that structure these perceptions, within the capacity of itemizing (van Hulst and Yanow, 2014: 3). The notion on itemizing is, therefore, an essential aspect for comprehending the perspective presented in this paper, in which fragmentation becomes an inherent part of an institutional practice of packing and unpacking what peace entails for its broader conceptualization in which lays the perspective of framing and reframing the social reality as an ad continuum process.

Although framing is not defined as static, Rein, and Schön (1993) point out one problematic aspect of framing. It "leads to different views of the world and creates multiple social realities" (Rein and Schön, 1993: 147), in which the fragmentation lays. Following their thought, there are different actors included in their analysis, such as interest groups and policy constituencies, scholars working in various disciplines, and individuals in different contexts of everyday life (Rein and Schön, 1993: 147). Together, they not only share frames, as well as they "have different frames that lead them to see different things, make different interpretations of the way things are, and support different courses of action concerning what is to be done, by whom, and how to do it" (Rein and Schön, 1993: 147). As Knaggård explains, "problem framing is an on-going process of framing and reframing, where competing frames offer different understandings of the world" (2013: 7), as well as different structures designed to act in the face of the problems identified.

In complementarity, van Hulst and Yanow affirm that there are three kinds of entities within the process of framing and reframing, which are: the substantive content of the policy issue, the identities and relationships of situational actors in the policy process, and the policy process itself (2014: 11). This is the reason why Joachim (2003) affirmed that framing and reframing an issue is an opportunity for engaging different actors in such a process and not be limited to a unique arena. As she states: "examining how issues are defined or framed is particularly important in this respect since this is the first step in interest formation and determines which institutions will take up these issues and which actors will pay attention to them" (Joachim, 2003: 249). In her analysis, the engagement of other actors rather than the institution in a framing process enables setting an agenda in three stages: "the definition of the problems, the development of solutions or policies, and politicization" (Joachim, 2003: 268). Autesserre, in her turn, complements Joachim's (2003) contribution, arguing that "frames shape how people understand the world and, based on this understanding, what they perceive to be appropriate action" (Autesserre, 2009: 252). Within an international interventionist perspective, Autesserre states that frames play an important role since they "can account for what shapes the international understanding of the causes of violence and the interveners' role, and how this understanding makes certain actions possible while precluding others" (2009: 252). In my perspective, such a process reveals not only the interpretation of the social reality per se, rather the possibility of establishing what should be the international design for achieving good results on the ground through a common perception of what entails the promotion of peace at a top-down level. 


\section{Peace constituencies within the SDG}

The concept of a positive approach to peace formulated by Galtung (1969) and its following interpretations through different authors give a direction on what are the levels of peace and, consequently, where lays its fragmentation when analyzed taking the role of the SDGs. First conceived on the idea of "the absence of structural violence"1 (Galtung, 1969), and its complement on the notion of a strategy to prevent war, exploitation and, mainly, the promotion of social justice in all its forms (Galtung, 1971, 1990), the concept of positive peace has been reinterpreted and criticized over decades to establish a more precise and pragmatic comprehension about it (Boulding, 1978; Jeong, 2005; Goertz, Diehl and Balas, 2016; Wallensteen, 2017).

Richmond (2006a), for example, mentions that collective calls for a positive peace are generally associated with idealism and that it is often dismissed as a binary concept indicating an absolute division between peace and war (Richmond, 2006a). His interpretation in the scope of this paper is based on nine from the 11 assertions ${ }^{2}$ he provides as an attempt to summarise what peace is, taking different perspectives through historical moments ${ }^{3}$. For Richmond (2008), these assertions reflect that peace is:

i. always aspired to and provides an optimum, though idealistic, point of reference;

ii. viewed as an achievable global objective, based on universal norms;

iii. viewed as a geographically bounded framework defined by territory, culture, identity and national interests;

iv. presented as objective truth, associated with complete legitimacy;

v. related to a particular ideology or political or economic framework;

vi. as a temporal phase;

vii. based upon state or collective security;

viii. based upon local, regional or global forms of governance, perhaps defined by a hegemonic actor or a specific multilateral institution; and

ix. viewed as a top-down institutional framework or a bottom-up civil society-oriented framework. (Richmond, 2008: 8-9)

Such division of peace based on this historical background and social contexts mentioned above elucidates not only a temporal perspective on peace but also a contribution to the analysis on how the concept was improved over time and how it is being pursued by the international community.

1 In Galtung's (1969) contribution, the 'absence of structural violence' is what is referred to as social justice, which is a positively defined condition (egalitarian distribution of power and resources).

2 Assertions 10 and 11 are, respectively, that there are needs to be little discussion of the conceptual underpinnings of peace because it is one ideal liberal form; and that the most thinking about peace in IR is predicated on preventing conflict, and at best creating an externally supported peace, not on creating a self-sustaining peace (Richmond, 2008: 8-9).

3 The international historical moments in which the peace was theme include: the Peace Alexandrina, military conquests; Pax Romana, rigid control of an imperial territory, also including the Cartegian Peace; The Augustinian Peace, adoption and territorial protection by Catholicism; The Peace of Westphalia, the security of the States and the territorial areas of sovereignty; The British Pax, British domination in the seas, trades and alliances with the colonies; The Paris Peace Treaty of 1919; The UN system, collective security, and international cooperation (Richmond, 2008: 7-8). 
As Richmond (2008) points out, the study of liberal peace has shown how different types of power arise from below and confront processes or institutions which do not represent context or critical agency, at the same time liberal peace "has not provided material benefit to its subjects and has emphasized local and global inequalities" (Richmond, 2008: 186). For this reason, the liberal peace model makes types of power and legitimacy visible, and they appear "to be fragmented and self-announced from the perspective of subjects who are under pressure not only to practice it but to make peace and produce a surplus" (Richmond, 2008: 186).

Besides, the author continued the debate on the liberal peace framework, including a post perspective " to create contextual hybridity from social, political, economic, cultural, and historical experiences of peace in local, transnational, and international terms" (Richmond, 2008: 188). For that, Richmond (2008) explained that

Hybridity has always been present in the transversal and transnational relationship between the local and the international. It is an attempt to escape liberal enclosure and distant administration, to take a stake in a much broader discussion of peace where even fragmented collective action or mobilization occurs inclusively rather than as an apparent diktat from a distant international community. (Richmond, 2008: 188-189)

In this sense, based on the hybridity perspective proposed by Richmond (2006a), peace may be understood and projected from either the inside of a political community or from its outside. Following his thought, peace may have a specific logic, derived from one particular political framework, such as democracy and constitutionalism; a specific international framework, characterized by the balance of power or institutionalism and governance; an economic framework, through free trade and markets; or a social framework, constructed and consolidated by a common or agreed identity or a mix of identities and human rights (Richmond, 2006a, 2006b).

When the UN adopted the SDGs as a global endeavor on September 2015 (UN Doc. A/RES/70/1), the document that gave birth to this approach was assertive in highlighting that the 2030 Agenda for Sustainable Development was designed, first, "to strengthen universal peace in larger freedom" (UN Doc. A/RES/70/1), which implies on the perspective that peace within the scope of the SDGs was frame as a collective design for all countries despite differences on their respective levels of development. For that reason, the promotion of peace through the SDGs requires, as Sachs (2012) points out, "unprecedented mobilization of global knowledge operating across many sectors and regions" (2012: 2211), corroborating to the perspective that peace through the SDGs is an exemplification of hybridity (Richmond, 2008; Kolk and Lenfant, 2017) in a fragmented manner. As Sachs continues,

governments, international institutions, private business, academia, and civil society will need to work together to identify the critical pathways to success, in ways that combine technical expertise and democratic representation. Global problem-solving networks for sustainable development - in energy, food, urbanization, climate resilience, and other sectors - will, therefore, become crucial new institutions in the years ahead. (Sachs, 2012: 2211) 
Beyond this perspective, the institutional notion over the emergence of the SDGs was based on the argument that SDGs were there "to build on the Millennium Development Goals and complete what they did not achieve" (UN Doc. A/RES/70/1), calling for a momentum in which a reinterpretation of the challenges was required one more time to go against global and common problems. Such institutional recognition is an essential aspect for comprehending that institutional practices do change over time, and such changes imply a different way of interpreting social reality. Although I emphasize that such reinterpretation is part of an ad continuum process, my perspective is corroborated by authors who argue that the SDGs "are a follow up of Millennium Development Goals (MDGs) but with some major differences" (Arora and Mishra, 2019: 339); and that their 17 goals were to build upon based in an extended version of the MDGs while transforming dominant approaches to economic, social, and environmental challenges (Biermanna, Kanieb, and Kim, 2017: 26; Stevens and Kanie, 2016: 394; Hák, Janoušková, and Moldan, 2016: 566). In this regard, the 17 goals designed for the SDGs in 2015 - as highlighted on Table 1 - not only represent minor aspects of what peace entails in a fragmented broader conceptualization (UN, 2019: online), instead they reflect a hybridity perspective that peace involves a dynamic process of interaction between what is designed at the top level to what is implemented at the bottom level.

Table 1: Sustainable Development Goals

\begin{aligned} \hline 1 & No Poverty \\ 2 & Zero Hunger \\ 3 & Good Health and Well-Being \\ 5 & Quality Education \\ 6 & Gender Equality \\ 7 & Affordable and Clean Energy \\ 8 & Decent Work \& Economic Growth \\ 9 & Industry, Innovation, and Infrastructure \\ 10 & Reduced Inequalities \\ 11 & Sustainable Cities and Communities \\ 12 & Responsible Consumption and Production \\ 13 & Climate Action \\ 14 & Life Below Water \\ 15 & Life on Land \\ 16 & Peace, Justice and Strong Institutions \\ 17 & Partnerships for the Goals \\ \hline Source: & UN (2019). \end{aligned}


Back to Richmond's (2006a) analysis, all these variants - or goals - can be observed as the foci of the construction of peace during the development of the modern international system. In this regard, the author affirms that peace could also be associated with a method to provide social welfare as its priority. Consequently, the construction of a new peace has depended increasingly upon a concurrence over an "ideal" peace by multiple actors operating in the different locations of the state, society, and international institutions and organizations, as well as strategies. To corroborate this perspective, there are two complementary thoughts: the interpretation of peace presented by Mac Ginty (2006) and the enlargement of the concept of positive peace by Claggett-Borne (2013). In both contributions, they do not bring new definitions of peace. What they discuss is based on Galtung's original contribution, on negative and positive peace, even though they enable to identify how peace is being fragmented not only in pragmatic terms, as well as in discursive ones. Based on Mac Ginty (2006), peace is "the facilitation of non-exploitative, sustainable and inclusive social relationships free from direct and indirect violence and the threat of such violence." Beyond this definition, the author presents a division of peace in eight levels:
i. cessation of hostilities
ii. democracy
iii. equity
iv. social justice
v. international stability
vi. ordered society
vii. shared pacific ideal
viii. personal wellbeing

The definition and justification of such division of peace are presented by the author as an extension beyond actual physical violence to encompass the threats and intimidation that shape so much of daily life in deeply divided societies. "If people are free from direct violence but subsist in conditions of extreme poverty without opportunities for advancement, then we cannot call that situation peace" (Mac Ginty, 2006), which is the main Galtung's argument.

From a different perspective, Claggett-Borne (2013) applied the concept of positive peace into a broader approach and proposed enlargement of this concept. In her contribution, "positive peace is another major category that include two subcategories as well as numerous tertiary subcategories." To clarify such fragmentation over her perspective, Claggett-Borne (2013) divided positive peace into i) prerequisites for peace and ii) outcomes ${ }^{4}$. Within the prerequisites for peace, there are an additional of seven descriptive subcategories of the particular requirements mentioned with the highest frequency, such as: granting of human rights, equality, acceptance/tolerance, democratic participation, openness

4 For outcomes, Clagget-Borne (2013) state that they reflect positive emotions, calm/tranquility, and harmony. 
to working toward a mutual goal, security, and access to resources (Claggett-Borne, 2013). Based on her perspective, it is possible to say that the conceptualization of peace embraces a process of strategy, which presumes on the establishment of a framework to be implemented; and the outcomes, which are the impact of such projects when implemented. Although Mac Ginty (2006) and Claggett-Borne (2013) did not mention the fragmentation of peace as a necessary process on the application of peace, the fragments presented above can be applied to different social contexts and be embedded into different perceptions. Beyond the discussion on the ideational aspect of peace and the subsequent interpretations of the concept, I aim to debate in this part of the paper that the academic perception on positive peace provided by Galtung (1969) supported its co-optation into different realms of practice offered by states, non-governmental organizations, international organizations and, also, multinational corporations. On behalf of peace, all these actors in the international system improved the strategies in which peace is being applied.

\section{SDGs: fragmenting the pattern of peace}

Since the purpose of this paper is to provide an understanding of the SDGs as a reframing process for comprehending social reality into a fragmented approach of defining different strategies for peace; such understanding only becomes evident when compared the goals comprised as part of the SDGs to its previous framework - the MDGs - as a perspective in which peace is embedded. As Arora and Mishra (2019) point out, MDGs were mainly focussed on poverty and hunger to mostly of the less developed countries, while the SDGs became applicable to all countries and regions of the globe. Such condition is necessary for enabling the identification of the fragmentation in which most of the Millennium goals work as a matrix for its predecessor framework. In their analysis, the 17 Sustainable goals became "much broader in their terms, extending to social and economic aspects of human society and their dimensions with the natural environment, by putting sustainability at the center" (Arora and Mishra, 2019: 339).

As MacArthur (2014) points out, the MDGs were established as a response to many of the world's foremost challenges as they appeared in 2000 for 15 years of implementation and framed around a "global plus national" strategy from the outset; and that the SDGs emerged in a context where the world's time-bound and quantified targets for addressing extreme poverty in its many dimensions - income poverty, hunger, disease, lack of adequate shelter, and exclusion - while promoting gender equality, education, environmental sustainability and human rights (UNDP, 2005) became an international and common call. The Millennium's mission was to "spare no effort to free men, women, and children from the abject and dehumanizing conditions of extreme poverty" (UN, 2015). For the international political system, "they [were] the fulcrum on which development policy is based" (UNDP, 2005: 2).

Once designed, each goal under the Millennium framework identifies specific development priorities across a vast range. "These goals have substantially shaped development dialogue and 
investment; some development agencies judge all their activities on the contribution to the achievement of the MDGs" (Waage, Banerji, and Campbell et al., 2010a: 992). As a consequence, "the MDGs have had a substantial effect, both with respect to focusing resources and efforts on important development objectives, and also more generally in raising public and political interest in the development agenda" (Waage, Banerji and Campbell et al., 2010a: 1007). As Sachs explains, "packaging these priorities into an easily understandable set of eight goals [initially] (...) help to promote global awareness, political accountability, improved metrics, social feedback, and public pressures" (2012: 2206).

Within this framing perspective, Sachs (2012) states that "the MDGs were targets mainly for poor countries, to which rich countries were to add their solidarity and assistance through finances and technology" (2012: 2208). Nevertheless, when the SDGs were established, the framing perspective over them was the one centered on the notion that they were "eluding the entire planet," thus being global in nature (Biermanna, Kanieb and Kim (2017: 28), in which they posed "goals and challenges for all countries, and not what the rich should do for the poor, but what all countries together should do for the global wellbeing of this generation and those to come" (Sachs, 2012: 2208).

As a progressive achievement to peace, the SDGs were incorporated in the international system spectrum in 2015 for 15 years of execution to eradicate poverty in all its forms and dimensions, that represent a global challenge and an indispensable requirement for sustainable development agenda within three dimensions - economic, social and environmental - in a balanced and integrated manner (UNDP, 2005: 3). Its implementation requires a revitalized Global Partnership that will work in a spirit of global solidarity, to facilitate an intensive global engagement in support of the implementation of all the goals and targets, bringing together Governments, the private sector, civil society, the United Nations system and other actors and mobilizing all available resources (UN, 2015: 10). However, this holistic perspective in promoting social, economic and environmental benefits can be understood as a fragmented form of providing peace from, on the one hand, by the MDGs that designed eight goals to be achieved and, on the other hand, by the SDGs, that enlarged its predecessor version into 17 goals, as the table 2 shows.

Based on the table mentioned above, it is possible to argue that, first, each goal established in both MDGs and SDGs represents a perspective in avoiding different practices of structural violence. Second, avoiding these violent practices is the consolidation of a strategy that aims to achieve peace in its positive realm. Third, designing a framework to achieve positive peace in both frameworks represents a fragmentation of an international peace design, with the meaning that peace is consensually understood by a specific set of priorities. 
Table 2: Fragmenting peace from MDGs to SDGs

\begin{tabular}{ll}
\hline Millennium Development Goals & Sustainable Development Goals \\
\hline 1. Eradicate Extreme Poverty and Hunger & $\begin{array}{l}\text { 1. No Poverty } \\
\text { 2. Zero Hunger } \\
\text { 3. Good Health and Well-Being }\end{array}$ \\
\hline 2. Achieve Universal Primary Education & $\begin{array}{l}\text { 4. Quality Education } \\
\text { 8. Decent Work and Economic Growth }\end{array}$ \\
\hline 3. Promote Gender Equality and Empower Women & 5. Gender Equality \\
\hline 4. Reduce Child Mortality & 3. Good Health and Well-Being \\
5. Improve Maternal Health & \\
\hline 7. Combat HIV/Aids, Malaria and other Diseases & 6. Clean Water and Sanitation \\
& $\begin{array}{l}\text { 7. Affordable and Clean Energy } \\
\text { 13. Climate Action }\end{array}$ \\
$\begin{array}{ll}\text { 14. Life Below Water } \\
\text { 15. Life on Land }\end{array}$ \\
$\begin{array}{ll}\text { 9. Industry, Innovation, and Infrastructure } \\
\text { 10. Reduced Inequalities }\end{array}$ \\
$\begin{array}{ll}\text { 11. Sustainable Cities and Communities } \\
\text { 12. Responsible Consumption and Production } \\
\text { 17. Partnership for the Goals }\end{array}$ \\
\begin{tabular}{ll} 
16. Peace, Justice and Strong Institutions \\
\hline
\end{tabular}
\end{tabular}

Source: UN (2000b, 2016).

Besides, comparing goals established under the MDGs and to the SDGs, it is also possible to argue that the second ones were designed following a fragmentation from its first version, since the MDG works, in my perspective, as a matrix for the SDGs and also for what will come next when a new framework poses a collective call for reinterpretation when the timeframe for the SDGs is over. In this regard, such fragmentation becomes more evident when analyzed by both Millennium and Sustainable Development Goals concerning their respective structures: while the MDGs were designed focusing eight goals, 18 targets, and 48 indicators; SDGs were seen as "senseless, dreamy, garbled" (Easterly, 2015) for having 17 goals, 169 targets, and 230 indicators (Sridhar, 2016: 1453).

An example that illustrates this argument into a fragmenting process is provided by the first Millennium goal - eradicate extreme poverty and hunger - that was fragmented into three distinct goals within the current version: no poverty (1), zero hunger (2) and good wealth and wellbeing (3). Similar fragmentation is also seen on three more Millennium goals: Achieve Universal Primary Education (2), Ensure Environmental Sustainability (7), and Global Partnership (8) in which were fragmented into 12 different goals, already evident on table 2 . At this point, I highlight that understanding and identifying peace through a fragmentation process from previous to the current goals established by the UN is part of a framing process. This process reveals that strategies for peace, within international organizations, are reinterpreted continuously for better designs of institutional actions. 
Although the fragmentation of peace contemplates an enlargement of 4 MDGs into 15 SDGs, the non-fragmentation is also part of a reframing process, and it becomes essential for understanding the whole notion of peace within this framework. In this regard, I mention two cases: first, the MDG Promote Gender Equality and Empower Women (3) was reinterpreted and later labeled as Gender Equality (5) under the SDG, which means that the main difference among them lays on broadening the scope of their respective aims. While MDG 3 aims to "eliminate gender disparity in primary and secondary education, preferably by 2005, and in all levels of education no later than 2015"; the SDG 5 aims to "end all forms of discrimination against all women and girls everywhere," maintaining the main principle that guides both previous and current goal. Second, the MDGs Reduce Child Mortality (4), Improve Maternal Health (5), and Combat HIV/Aids, Malaria, and other Diseases (6) were combined into one main cluster, under the SDG Good Health and Well-Being (3). About this illustration, the combination refers to the notion that while these MDGs were focusing on three separated but inter-related goals, the SDG 3 incorporated them - reduce the global maternal mortality ratio, end preventable deaths of newborns and children, and end the epidemics of AIDS, tuberculosis, malaria and neglected tropical diseases and combat hepatitis - into a common cluster, as part of a reframing process.

Although fragmentation implies on an analysis of non-fragmentation as part of a process of interpreting challenges and opportunities for action, this analysis also enables discussing that fragmenting peace refers to the emergence of new goals that do not derive from any previous MDGs nor represent any combination of previous MDGs into a common SDG. To this, I refer to the SDG 16, which aims to promote peaceful and inclusive societies for sustainable development, provide access to justice for all and build effective, accountable, and inclusive institutions at all levels. As Henk-Jan Brinkman stated, goal 16 emerged in the context of filling a gap regarding what people were expecting as part of a UN response in that regard.

More than 7 million people voted on an online survey, and safety from crime and violence was among the top 7 priorities across the world, in all region among all population, including men and women. That's why it was very important [to provide] specific goal as an outcome for peace and not just argue that it is an enabler for the other goals or that peace is sometimes defined as broad as being free from want and free from poverty from one or another goal. (Brinkman, 2016) ${ }^{5}$

From his contribution, Brinkman contemplates SGD 16 as a significant accomplishment as a peace outcome in which its emergence reflects that it could play a role on addressing against "violent conflicts as the greatest threat to human development, and as the central obstacle to the timely implementation of the MDGs" (Vorrath and Beisheim, 2015: 2); that it could "represents an

5 This quote was provided by Henk-Jan Brinkman, Chief of the Policy Planning and Application Branch of the UN Peacebuilding Support Office, during his online presentation entitled "Measuring Goal 16", which was organized by the DME for Peace Thursday Talk, on 29 September 2016. I attended this online talk and addressed the question to Henk-Jan Brinkman, who provides the explanation I now use for analyzing in this article. The online talk is available at: <https://vimeo.com/184869493>. 
important innovation with potentially long-term implications" (Edwards and Romero, 2014: 141) since it "reframed the international agenda and creates new opportunities for policy advocates to collaborate" (Edwards and Romero, 2014: 144); and that Goal 16 could "lays out the central role for institutions, encompassing both their function and their ethos and logically puts politics at the heart of institutions" (Whaites, 2016: 2). Although goal 16 is the innovative (Edwards and Romero, 2014) and revolutionary (Schiano, Chelby and Ruíz, 2017) institutional response, it is, in its essence, the fragmentation of its scope, as table 3 highlights. Since it implies reducing all forms of violence concerning different contexts - varying from deaths, trafficking, arms flows, corruption - it also emerges as a promising action about strengthening institutions at the national level, reflecting a two-side effect of the same goal.

Table 3: Targets under the SDG 16

\subsection{Significantly reduce all forms of violence and related death rates everywhere}

16.2 End abuse, exploitation, trafficking, and all forms of violence against and torture of children

16.3 Promote the rule of law at the national and international levels and ensure equal access to justice for all

16.4 By 2030, significantly reduce illicit financial and arms flows, strengthen the recovery and return of stolen assets and combat all forms of organized crime

16.5 Substantially reduce corruption and bribery in all their forms

16.6 Develop effective, accountable, and transparent institutions at all levels

16.7 Ensure responsive, inclusive, participatory, and representative decision-making at all levels

16.8 Broaden and strengthen the participation of developing countries in the institutions of global governance

16.9 By 2030, provide legal identity for all, including birth registration

16.10 Ensure public access to information and protect fundamental freedoms, in accordance with national legislation and international agreements

16.a Strengthen relevant national institutions, including through international cooperation, for building capacity at all levels, in particular in developing countries, to prevent violence and combat terrorism and crime

16.b Promote and enforce non-discriminatory laws and policies for sustainable development Source: UN (2019).

On this issue, I bring Kim's (2016) contribution, who also used the term "fragmentation" to explain that "the SDGs might be instrumental in orchestrating international institutions towards the common objective (...), and how international law provides a normative environment for the SDGs" (Kim, 2016). In his contribution, "the SDGs mirror the fragmented and compartmentalized structure of international law" (2016: 17) and, for this reason, his analysis provides the notion "that each SDG has multiple orchestrators, which in turn need to be orchestrated" (Kim, 2016: 19) following three levels of analysis: orchestration within an SDG, across a few SDGs in the same goal cluster, and across the economic, social and environmental goals of sustainable development (Kim, 
2016:17-18). In this regard, Kim's analysis corroborates to the argument I have elucidated along this article, in which the SDGs are not only a derivative of its previous framework - the MDGs - instead, they are a reinterpretation of the previous goals into common clusters or a compilation of different goals into a specific strategy under the scope of peace.

In this regard, the inclusion of the SDG 16 is, in essence, a strategy that directly connects to the concept of positive and negative peace provided by Galtung (1969). Not that the other goals do not address peace to some extent, but that attaching the term 'peace' to a goal represents the applicability of such conceptualization and what it implies for peace itself. As Ferreira elucidates, SDG 16 recognizes that development is inextricably linked to the idea of peace and justice (2019: 255, free translation) and, for this reason, it is not possible to study only the possibilities of peace by focusing on international conflicts or the struggle between states (Ferreira, 2019: 260, free translation), but that focusing on issues such as violence, inequality, justice, reconciliation and conflict resolution (Ferreira, 2019: 260, free translation). Consequently, SDG 16 and the whole framework aim to transforming the social structures that perpetuate and reproduce social injustice, crystallized in what Galtung conceptualizes as structural violence (Vorrath and Beisheim, 2015: 2; Ferreira, 2019: 263, free translation) from an approach that delimitates the end of direct violence to an approach that enlarges the notion on peace into more cohesive social structures.

Embedded in this approach, I point out that connecting SDG 16 to the notion of positive and negative peace proposed by Galtung (1969) is its main strengths. This also does not neglect other goals concerning their respective contribution to peace, but that taking SDG 16 as innovative, it is accepted as of "central significance for the overall success of the agenda" (Vorrath and Beisheim, 2015). Beyond this, Edwards and Romero (2014) point out that SDG 16 has the potential to be profoundly innovative in three fronts: first, "it represents a restatement of the central importance of good governance as an aspirational goal in the UN system" (Edwards and Romero, 2014: 141-142), which implies on the discussion on reforming the UN institutions; second, "it has important policy implications for fragile states because it focuses attention on the need for better governance as a way to escape the conflict trap" (Edwards and Romero, 2014: 141-142); and, third, "it reinforces this importance for developed countries by stressing the necessity of inclusion" (Edwards and Romero, 2014: 141-142).

Even though Edwards and Romero (2014) have stated that "goal 16 was written with fragile states in mind" (2014: 146), I point out that providing a SDG within this approach is part of its limited character. They argue that "goal 16 sheds light on the idea that established democracies are far from perfect; there are issues that remain unsolved even in the West" (Edwards and Romero, 2014: 147-148) and that it could "act as a catalyst that can bring forth new strategies to improve participation in elections, improve trust in the government, and curb anti-government movements" (Edwards and Romero, 2014: 147-148). In my perspective, the notion of fragility is not a static one and permeates different levels even of a country not labeled as failed. This is the reason why SDGs were enlarged and incorporated to all countries in contrast to the ones that became recipient of the MDGs only. The universalization of the SDGs enables an understanding that different practices of 
violence - be they direct or structural - are located even in most higher developed countries and countries with a possess of a less level of fragility; otherwise there was no need to provide a common framework for sustainability.

Another limitation aspect related to the implementation of the SDG 16 refers to measurement. As Whaites explains, "measuring progress towards achieving the proposed goal and targets is problematic" (2016: 3). The author goes beyond such a statement providing an explanation arguing that "there are no safe, easily achievable, targets" (Whaites, 2016:3) and that "these targets are not themselves a linear path to the overall goal” (Whaites, 2016:3). As a result of such limited aspect, Whaites argues that, on the one hand, "stakeholders must work to deliver the targets while keeping a careful eye on the horizon to maintain a route towards the goal itself" (Whaites, 2016: 4), while, on the other hand, "the question is whether [national governments] will enhance the impact of each other's efforts, or dissipate impact through inchoate approaches" (Whaites, 2016: 10). In this sense, fragmenting peace reveals not only breaking into pieces a more general idea of the term, rather evidencing strengths and limitations such fragmentation evolves.

\section{The logic behind the fragmentation}

The logic behind the fragmentation of peace through the SGDs lays on the notion that their respective goals reflect specific missions in which different actors are committed to achieving a positive impact when these policies-oriented target goals are implemented. Different in number and name from its first version, the purpose of this 'world transformation' by the UN is the end of structural violence and, consequently, the promotion of positive peace by a fragmented framework to reach its holistic comprehensiveness. Nevertheless, as Deffner and Hoerning (2011) emphasized in the begging of this essay that the fragment appears as part of an original entity which may no longer appear as such, it remains to know how this fragmented peace will converge and, consequently, how it is becoming standardized by the international community. As points Miklian (2017), the UN Security Council included corporate stakeholders in the drive to attain the Millennium Development Goals, calling for more investment in fragile conflict areas to stimulate development, at the same time the UN recognized that economic underdevelopment could be conflict-generating (Miklian, 2017: 4) since they were initially designed for developing countries. Within the SDGs, the engagement is more holistic, building a sense of collective endeavor in which different stakeholders embrace SDGs as a national discourse in pursuing a new set of norms.

Besides, Kolk (2016: 3) emphasized that the academic and managerial agendas are to some extent influenced by policy debates, which have become very vibrant recently by, for example, the reasons that explain why the UN was moving from the Millennium Development Goals to the Sustainable Development Goals at that time. In the same line of thought, Rettberg (2016) points out that not only the establishment of both MDGs and SDGs was marked with the essence in business conception (Forrer et al., 2012), but the period of transition from MDGs to SDGs, is where lays the concept of 
business in the promotion of peace. In the author's analysis, while the MDGs were signed to reduce extreme poverty, they included a resolution to "develop strong partnerships with the private sector and with civil society organizations in pursuit of development and poverty eradication" (Rettberg, 2016: 3; UN, 2000), while, in 2013, the former Secretary-General Ban Ki-moon launched the business leadership platform Business for Peace (B4P) to mobilize greater engagement of business in support of the peace-related activity. As part of the SDGs design, "companies have been called upon to play an active role in the implementation of the goals" (Rettberg, 2016:4) that also "align with business motivations to gain access to new consumer markets in fragile developing states" (Miklian, 2017: 4).

Although this fragmented process reveals a positive approach of designing peace through what have been consensually constructed as part of its historical conceptualization, this "process also generated a framework that reveals potential conflicts and synergies between goals, and how their interactions might be governed" (Waage, Banerji, Campbell et al. 2010a: e251). As they explain, "by simply gathering together established goals and targets of these different development communities, the MDGs could not hope to achieve the desired integrated approach that is appropriate to complex problems in international development. Worse, by fostering traditional and institutional ownership of different MDG goals, the MDGs reinforced their isolation” (Waage, Banerji, Campbell et al, 2010b: 1000).

Consequently, Waage, Banerji, Campbell, et al. (2010b) argue that such fragmenting process also creates some gaps and that the millennium "goals and targets not only emphasize the omission of important development needs but also fail to realize efficiencies and even synergies arising from the potential links between goals" (Waage, Banerji, Campbell et al, 2010b: 997), also leading to some missing opportunities to improve development outcomes (Waage, Banerji, Campbell et al, 2010b: 1000). Consequently, the development of both MDGs and SDGs is embedded within the necessity of improving global partnerships to foster peace through economic growth, responsible consumption, and production, as well as through the creation of international standards of promoting quality in life.

\section{Conclusion}

The perspective on taking the MDGs and the SDGs established by the United Nations represents a first step in thinking about how peace, from a holistic view, is being implemented in a fragmented manner. This means that the international system is conceiving different approaches to create a more assertive and pragmatic global objective, including the partnership of a variety of actors and agencies. This is the reason why fragmenting peace is symbolized through the establishment of the goals in both programs. Once both MDGs and SDGs congregate the same time - 15 years - for implementation, execution, and conclusion, it is possible to identify not only evolution on the peace plan in the field, through the enlargement of the goals - from 8 of the MDGs to 17 of the SDGs -, as well as an internal process of fragmentation of some of the established goals to its current version. 
The fragmentation process at this stage does not represent a problem to the promotion of peace in a first glance. However, fragmenting what has been fragmented already represents the continuation of a challenge that must be diminished. In this sense, how many fragments are necessary to consolidate a holistic peace plan? In the years will come, how many pieces will originate other ones? These questions do not have an answer in a first glance. They just enable us to discuss how the international system is continuously improving its strategy to foster peace in a fragmented manner. However, this process of fragmentation not only identifies the actors involved in promoting peace, as well as brings to the surface different structures that are embedded in such a process. The results concerning the impact on the ground, are still an issue of concern since the SDGs replaced its predecessor to attend the challenges MDGs were not capable of achieving. If the fragmentation designed to be implemented, causing another fragmentation with a negative impact on the ground, then positive peace is regressing to just a mere conception.

\section{References}

Adler, Emmanuel and Pouliot, Vincent (2011a). "International practices: introduction and framework" in Adler, Emmanuel and Pouliot, Vincent, International Practices, Cambridge: Cambridge University Press, 3-35.

Adler, Emmanuel and Pouliot, Vincent (2011b). "International Practices". International Theory, 3, 1-36. Arora, N. K. and Mishra, I. (2019). United Nations Sustainable Development Goals 2030 and environmental sustainability: race against time. Environmental Sustainability (2019) 2:339-342. DOI: https://doi.org/10.1007/s42398-019-00092-y. Accessed 31 Jan. 2020.

Autesserre, S. (2009). Hobbes and the Congo: Frames, Local Violence, and International Intervention, International Organization, 63(2), 249-280. doi: 10.1017/S0020818309090080. Accessed 31 Jan. 2020.

Berger, B. (1974). 'Foreword' in Goffman, E. (ed.) Frame Analysis: An Essay on the Organization of Experience. Boston: Northeastern University Press, i-viii.

Biermanna, F.; Kanieb, N. and Kim, R. E. (2017). Global governance by goal setting: the novel approach of the UN Sustainable Development Goals. Current Opinion in Environmental Sustainability 2017, 26-27:26-31. DOI: http://dx.doi.org/10.1016/j.cosust.2017.01.010.

Boulding, K. (1978). Stable Peace. Austin: University of Texas Press.

Brinkman, Henk-Jan (2016). Statement provided during the DME for Peace Thursday Talk entitled "Measuring Goal 16" on 29 September 2016. Available at: <https://vimeo.com/184869493>. Accessed on 20 June 2020.

CDCS (2004). A new strategy for Social Cohesion European Committee for Social Cohesion: A revised strategy for Social Cohesion. Available at: www.coe.int/t/dg3/socialpolicies/socialcohesiondev/ source/RevisedStrategy_en.pdf. Accessed 31 Jan. 2020.

Claggett-Borne, Elizabeth (2013), "Definitions of Peace and Reconciliation" in Malley-Morrison et al. (2013) International Handbook of Peace and Reconciliation. New York: Springer. 
Cunningham, Kathleen Gallagher (2016). Understanding fragmentation in conflict and its impact on prospects for peace. Oslo Forum Papers, 006 December.

Deffner, Veronika and Hoerning, Johanna (2011) "Fragmentation as a Threat to Social Cohesion? A Conceptual Review and an Empirical Approach to Brazilian Cities", International RC21 Conference, Amsterdam, July 2011. Unpublished conference paper. <www.rc21.org/conferences/ amsterdam2011/edocs2/Session\%2015/15-1-Deffner.pdf $>$. Accessed 31 Jan. 2020.

Easterly, W. (2015). The SDGs Should Stand for Senseless, Dreamy, Garbled. Foreing Policy. <https:// foreignpolicy.com/2015/09/28/the-sdgs-are-utopian-and-worthless-mdgs-development-rise-ofthe-rest/>. Accessed 31 Jan. 2020.

Edwards, Martin \& Romero, Sthelyn (2014). Governance and the Sustainable Development Goals: Changing the Game or More of the Same? SAIS Review, vol. 34, no. 2.

Entman, R. M. (1993). 'Framing: Toward Clarification of a Fractured Paradigm'. Journal of Communication, 43: 51-58. doi:10.1111/j.1460-2466.1993.tb01304.x. Accessed 31 Jan. 2020.

Forrer, John, Timothy Fort and Raymond Gilpin. (2012). "How Business Can Foster Peace.” United States Institute of Peace Report. Washington DC: USIP.

Ferreira, M. A. S. V. (2019) ODS 16 - Promover sociedades pacíficas e inclusivas para o desenvolvimento sustentável, proporcionar o acesso à justiça para todos e construir instituições eficazes, responsáveis e inclusivas em todos os níveis. In: Henrique Z. Menezes. (Org.). Os objetivos de desenvolvimento sustentável e as relações internacionais. João Pessoa: UFPB, 2019, p. 255-268.

Franklin, Alan B.; Noon, Barry R.; George, T. Luke (2002). “What is habitat fragmentation?”, Studies in Avian Biology, No. 25: 20-29.

Galtung, Johan (1969), "Violence, peace and peace research", Journal of Peace Research, vol. 6(3), pp. 167-191.

Galtung, Johan (1971), "What is a Good Peace Proposal”, Security Dialogue, 2: 291-294.

Galtung, Johan (1990), "Violence and Peace" in Smoker et al (1990) A Reader in Peace Studies. Oxford: Pergamon Press.

Goertz, G., Diehl, P. and Balas, A. (2016). The Puzzle of Peace: The Evolution of Peace in the International System. New York: Oxford University Press.

Hák, T; Janoušková, S. and Moldan, B. (2016). Sustainable Development Goals: A need for relevant indicators. Ecological Indicators, 60, 565-573. DOI: http://dx.doi.org/10.1016/j.ecolind.2015.08.003. Accessed 31 Jan. 2020.

Jeon, H. (2005). Peacebuilding in Postconflict Societies: Strategy and Process. London: Lynne Rienner Publishers.

Joachim, J. (2003). 'Framing Issues and Seizing Opportunities: The UN, NGOs, and Women's Rights. International Studies Quarterly, 47(2), 247-274. Retrieved February 1, 2020, from www.jstor. org/stable/3693544. Accessed 31 Jan. 2020.

Kim, Rakhyun (2016). The Nexus between International Law and the Sustainable Development Goals, Review of European Comparative \& International Environmental Law. Abril, Vol. 25, no. 1, p. 15-26. 
Knaggård, A. (2013). Framing the Problem: Knowledge Brokers in the Multiple Streams Approach. Paper presented at ECPR Joint Sessions of Workshops, 2013, Mainz, Germany. Retrieved from: <https://lucris.lub.lu.se/ws/files/6403258/5337344.pdf>. Accessed 31 Jan. 2020.

Kolk, An (2016). "The social responsibility of international business: From ethics and the environment to CSR and sustainable development." Journal of World Business 51(1):23-34.

Kolk, Ans and Francois Lenfant (2017). "Hybrid Business Models for Peace and Reconciliation." Business Horizons, forthcoming.

Larsen, Christian A. (2013). The Rise and Fall of Social Cohesion: The Construction and De-construction of Social Trust in the US, UK, Sweden and Denmark. Oxford University Press.

Larsen, Christian A. (2014). Social cohesion: definition, measurement and developments. $<$ www.un.org/esa/socdev/egms/docs/2014/LarsenDevelopmentinsocialcohesion.pdf $>$. Accessed 31 Jan. 2020.

MacArthur, John W. (2014). "The Origins of the Millennium Development Goals", SAIS Review, vol. XXXI,V no. 2 (summer/fall 2014).

Mac Ginty, Roger (2006). No War, No Peace: The Rejuvenation of Stalled Peace Processes and Peace Accords. New York: Palgrave Macmillan.

Miklian, Jason. (2017). "Mapping Business-Peace Interactions: Five Assertions for How Businesses Create Peace." Business, Peace and Sustainable Development, forthcoming.

Moncrieffe, J. (2007). 'Introduction. Labelling, Power and Accountability: How and Why 'Our' Categories Matter' in Moncrieffe, J. and Eyben, R., The Power of Labelling: How People Are Categorized and Why it Matters. London: Earthscan, pp. 1-16.

Rein, M. \& Schön, D. (1993). 'Reframing Policy Discourse' in Fischer, F. \& Forester, J. (eds.), The Argumentative Turn in Policy Analysis and Planning. London: University College London Press, pp. 145-166.

Rettberg, Angelika (2016). "Need, Creed, and Greed: Understanding Why Business Leaders Focus on Issues of Peace.” Business Horizons 59(5):481-492.

Richmond, Oliver P. (2006a) “Patterns of Peace”, Global Society, 20: 4, 367-394.

Richmond, Oliver P. (2006b), "The problem of peace: understanding the 'liberal peace”, Conflict, Security \& Development, 6:3, 291-314.

Richmond, Oliver P. (2008) Peace in International Relations. Abingdon: Routledge.

Sachs, Jeffrey D (2012). From Millennium Development Goals to Sustainable Development Goals. Lancet 2012; 379: 2206-11.

Schiano, Austin; Chelbly, Juan; Ruiz, Federico (2017). Sustainable Development as a Path to Peacebuilding: Finding Common Ground to Counter the Extremist Narrative, Seton Hall Journal of Diplomacy and International Relations, vol. 18, no. 1.

Sridhar, Devi (2016). Making the SDGs useful: A Herculean task. The Lancet: Comment. <http://dx.doi.org/10.1016/S0140-6736(16)31635-X>. Accessed 31 Jan. 2020.

Stevens, C. and Kanie, N. (2016). The transformative potential of the Sustainable Development Goals (SDGs). International Environment Agreements (2016) 16:393-396. DOI: 10.1007/s10784-0169324-y. Accessed 31 Jan. 2020. 
UN (2000). The Millennium Development Goals. Department of Public Information.

UN (2015). Millennium Development Goals Report 2015. New York: United Nations Press. <www. un.org/millenniumgoals/2015_MDG_Report/pdf/MDG\%202015\%20rev\%20(July\%201).pdf>. Accessed 31 Jan. 2020.

UN (2016). Transforming our world: the 2030 Agenda for Sustainable Development. Resolution adopted by the General Assembly on 25 September 2015. <http://www.un.org/ga/search/view_doc. asp?symbol=A/RES/70/1\&Lang=E $>$. Accessed 31 Jan. 2020.

UN (2019). Sustainable Development Goal 16. <https://sustainabledevelopment.un.org/sdg16>. Accessed 31 Jan. 2020.

UN Doc. A/RES/70/1. Resolution adopted by the General Assembly on 25 September 2015. Transforming our world: the 2030 Agenda for Sustainable Development. <www.un.org/en/development/desa/ population/migration/generalassembly/docs/globalcompact/A_RES_70_1_E.pdf $>$. Accessed 31 Jan. 2020.

UNDP (2005). The Millennium Development Goals Report 2005. New York: United Nations.

Van Hulst, M. \& Yanow, D. (2016). 'From Policy 'Frames' to 'Framing': Theorizing a More Dynamic, Political Approach'. American Review of Public Administration, Vol. 46(1), 92-112. DOI: 10.1177/0275074014533142. Accessed 31 Jan. 2020.

Vorrath, Judith; Beisheim, Marianne (2015). Organised crime in the "2030 Agenda for Sustainable Development": indicators and measurements for international and national implementation. SWP Comment, v. 45.

Waage J, Banerji R, Campbell O, et al. (2010a) The Millennium Development Goals: a cross-sectoral analysis and principles for goal setting after 2015. Lancet, 376: 991-1023.

Waage J, Banerji R, Campbell O, et al. (2010b) The Millennium Development Goals: a cross-sectoral analysis and principles for goal setting after 2015. Lancet, Comment; 376: 991-1023.

Wallensteen, P. (2017). Quality Peace: Peacebuilding, Victory, and World Order. New York: Oxford University Press.

Whaites, Alan (2016). Achieving the Impossible: Can We Be SDG 16 Believers? GovNet Background Papers No. 2, OECD. 